\title{
Unani Treatment Improved Fibrosis in Decompensated Cirrhosis of Liver: A Case Series
}

\author{
Mohammad Akhtar Siddiqui ${ }^{1}$, Shabnam Ansari ${ }^{1 *}$
}

${ }^{1}$ Department of Moalejat (Medicine), Faculty of Medicine (U), Jamia Hamdard, New Delhi, India.

\section{DOI Name}

http://dx.doi.org/10.3126/jaim.v4i2.16898

\section{Keywords}

Cirrhosis of liver, Unani Medicine, Complementary Medicine, hepatoprotective, regenerative herbs,

traditional medicine

\section{Citation}

MohammadAkhtarSiddiqui, Shabnam Ansari. Unani treatment improved fibrosis in decompensated cirrhosis of liver: A case series. Journal of Advances in Internal Medicine 2015;04(02):61-66.

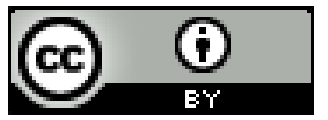

This work is licensed under a Creative Commons Attribution 3.0 Unported License.

\begin{abstract}
Introduction

At present, liver transplantation remains the only curative option for the patients with cirrhosis and end-stage liver diseases. The survival rate and recurrent diseases remains the major issue in the patient post-transplantation. Unani medicine is one of the oldest traditional system of medicine, has been treating chronic liver diseases and cirrhosis [Talayyaful-Kabid] since centuries. The purpose of our study was to assess the impact of Unani treatment in decompensated cirrhosis and collect data to warrant further clinical trials.

\section{Case presentation}

We have conducted a case series with three patients of decompensated cirrhosis and portal hypertension. Cases were confirmed by fibroscan and ultrasound and treated with Unani treatment orally for 3 months. Results were evaluated based on fibroscan, liver function test, EQ5D and TTO-TIME [tradeoff question].

\section{Conclusions}

Significant improvement in liver function test, fibrosis and quality of life were achieved in the patients. We reviewed the literature related to the herbal constituents of chief medicines used for the treatment in this case. The herbs have been proved for its potential anti-oxidative, anti-inflammatory, hepatoprotective, immuno-modulator and antiviral activities, suggesting plausible mechanisms of action in these cases. The preliminary findings indicate the potential therapeutic role of Unani treatment in decompensated cirrhosis. Clinical trials should be conducted to explore the further therapeutic potential of Unani treatment in decompensated cirrhosis.
\end{abstract}

\section{INTRODUCTION}

Cirrhosis is defined as the histological development of regenerative nodules surrounded by fibrous bands in response to chronic persistent liver injury, which leads to portal hypertension, ascites and end-stage liver disease. Liver fibrosis is a dynamic process which results from the perpetuation of the normal wound healing response resulting in an abnormal continuation of fibrogenesis [connective tissue production and deposition]. ${ }^{1-5}$ Progresses of fibrosis occurs at variable rates, depending on the cause of liver disease, environmental and host factors. ${ }^{1}$ The major clinical consequences of cirrhosis are impaired hepatocyte [liver] function, an increased intrahepatic resistance [portal hypertension], ascites and the development of hepatocellular carcinoma $[\mathrm{HCC}]^{1,2,5}$

Alcoholic liver disease and hepatitis $C$ are the most common etiologies of liver fibrosis in the Western world, while hepatitis B prevails in most parts of Asia and sub-Saharan Africa. ${ }^{1}$ Alcohol consumption is estimated to cause from $20 \%$ to $50 \%$ of cirrhosis of the liver. ${ }^{3}$ After the identification of the hepatitis $\mathrm{C}$ virus in 1989 and of non-alcoholic steatohepatitis [NASH] in obese and diabetic subjects, the diagnosis of cirrhosis without an apparent cause [cryptogenic cirrhosis] is rarely

\footnotetext{
* Corresponding author

Dr. Shabnam Ansari, MD Scholar

Department of Moalejat

Faculty of Medicine (U), Jamia Hamdard, India.

drshabnamansari.md@gmail.com
} 
made. Epidemiological studies shows that identified regular [moderate] alcohol consumption, age above 50 years, and male gender as risk factors in chronic hepatitis $C$, or older age obesity, insulin resistance/type 2 diabetes, hypertension and hyperlipidemia [all features of the metabolic syndrome] in NASH. Approximately $10-20 \%$ of patients with chronic HBV or $\mathrm{HCV}$ infection have cirrhosis at first clinical presentation, and as many as $20-30 \%$ of those who do not have cirrhosis will eventually develop this condition and its complications within one or more decades. ${ }^{2}$

Liver cirrhosis is a significant cause of global health burden, with more than one million deaths in 2010. Mortality from liver cirrhosis was also comparatively high in countries of Central Asia, particularly Mongolia, Uzbekistan and Kyrgyzstan, and in parts of sub-Saharan Africa. ${ }^{4}$

The physicians of Unani system of Medicine have been treating cirrhosis of liver and its consequences since centuries. The entity "Warm-e-Jigar Barid Saudawi"/ "Taleef-ul-Kabid" in Unani literature, mimic liver cirrhosis and associated constellation of symptoms. A large number of single and compound drug preparation have been documented in the treatment of Taleef-ul-Kabid. These scientific studies have validated the antioxidant, anti-inflammatory, antiviral, immuno-modulatory, and hepatoprotective nature of plant-based medicines, and their bioactive principle has been isolated and characterized. The cases who were treated in the present series includes only those who were advised for liver transplantation. Due to nonavailability of donor and certain factors such as restricted and costlier resources in overpopulated India, Unani treatment has been given in these cases as per Unani paradigms documented in Unani literature for cirrhosis of liver. Unani treatment, given in this case series comprised of multiple poly-herbal or compound preparation of Unani medicine.

\section{OBJECTIVE}

Present case series was performed, primarily aimed to explore the antifibrotic and liver regenerating effect of Unani treatment in the three cases of liver cirrhosis.

\section{CASE PRESENTATION}

\section{Consent}

Informed consent was taken from the patients. The human data's, included in this case series were obtained in compliance with the Declaration of Helsinki.

\section{Outcome measures}

Results were evaluated based on clinical manifestation and investigation such as fibroscan, liver function test and findings of ultrasonography of abdomen. Assessment of quality of life was also done using EQ5D and TTO-TIME [trade-off question] section 37 of physical health version 2, October 2005, pre and post-Unani treatment.

Case 1: S.J 40 years Indian male admitted to the in-patient department of Majeedia Unani Hospital [MUH] on February 13, 2015 with chief complains of 1] fever 2] dark yellow coloration of urine 3] pain in abdomen 4] constipation 5] distension of abdomen 6] loss of appetite and 7] general weakness for one and half months. Patients complained of chronic weakness and indigestion since two years. No prior history of jaundice was found although patient reported history of blood donation 7 years ago. Patient was investigated with haemogram, liver function test, kidney function test, ultrasonography abdomen, fibroscan of liver and viral hepatitis profile. Patient was diagnosed as a case of chronic hepatitis B complicateddecompensated cirrhosis of liver with portal hypertension, gross ascites and contacted edematous gall bladder with left renal calculus, confirmed by ultrasonography of abdomen and fibroscan. Viral count was $1,88,115 \mathrm{IU} / \mathrm{ml}$ on $19^{\text {th }}$ February 2015. The serum bilirubin total, alanine transaminase [SGPT], alkaline phosphatase were $17.05 \mathrm{mg} / \mathrm{dl}, 1271 \mathrm{IU} / \mathrm{L}$, and 407 IU/ $L$ respectively on $13^{\text {th }}$ February 2015. PT, APTT, INR wasn't found deranged. First fibroscan of liver was done, revealed ' $E$ ' median $45,0 \mathrm{kPa}$ and 'CAP' median $148 \mathrm{~dB} / \mathrm{m}$ on $24^{\text {th }}$ February 2015,. Unani treatment [started from $14^{\text {th }}$ February] specific for etiology, given in this case consisted of

1) Primarily decoction of shahtara [Fumaria officinalis], sarphookah [Tephrosia purpurea], chiraita [Swertia chiraita], gule mundi [Sphaeranthus indicus], sandal surkh [Pterocarpus Santalinus], tukhm kasni [Cichorium intybus], tukhm saddab, and barg makoh [Solanum nigrum] 5 g each, in the morning, empty stomach, started since admission. Barg-e-hina [Lawsonia inermis], birhamdandi [Echinops echinatus], burada aabnoos [Diospyros ebenum], gule surkh [Rosa damsecenes], tukhm-e-kasni [Cichorium intybus], tukhm-e-branjasif [Achillea millefolium], were added in the above decoction formula, $5 \mathrm{~g}$ each on $5^{\text {th }}$ march 2015.

2) Arq makoh [Aqueous extract Solanum nigrum] $50 \mathrm{ml}+$ Arq kasni [Aqueous extract Cichorium intybus] 50ml+Arq biranjasif [Aqueous extract Achillea millefolium] 50ml, combined, twice daily,

3) Powder of afsanteen [Artemisia absinthium], tukhm-ekasni [Cichorium intybus], qust [Saussurea lappa], $5 \mathrm{~g}$ each is started from $5^{\text {th }}$ March 2015

4) Habbe Kabid Naushadri, 2 tablet twice daily after meal 


\section{5) Habbe Halteet, 2 tablet twice daily after meal}

Repeated assessment of liver function test and urine analysis were performed weekly. On $21^{\text {st }}$ March, serum bilirubin total, SGPT, Alkaline phosphatase and gamma glutamyl transferase [GGT] were reduced to $10.62 \mathrm{mg} / \mathrm{dl}, 295.67 \mathrm{IU} / \mathrm{L}, 463.48 \mathrm{IU} / \mathrm{L}$ and $206.9 \mathrm{U} / \mathrm{I}$ respectively. Another analysis of LFT on $31^{\text {st }}$ March 2015 showed further reduction in serum bilirubin total, SGOT, alkaline phosphatase and GGT values to $9.76 \mathrm{mg} / \mathrm{dl}$, $186.1 \mathrm{IU} / \mathrm{L}, 358.07 \mathrm{IU} / \mathrm{L}$ and $186.31 \mathrm{U} / \mathrm{I}$ respectively. Second ultrasonography abdomen was performed on $25^{\text {th }}$ March 2015, showed a mildly enlarge liver, no free fluid and nondilated portal vein and left renal calculus. A repeat fibroscan on $25^{\text {th }}$ March 2015 [approx. after 6 weeks of Unani treatment] revealed a definite reduction in liver fibrosis to ' $E$ ' median 27,0 $\mathrm{kPa}$ and 'CAP' median $185 \mathrm{~dB} / \mathrm{m}$ from ' $\mathrm{E}$ ' median 45,0 kPa and 'CAP' median $148 \mathrm{~dB} / \mathrm{m}$. Haemogram and KFT remain normal pre and post- Unani treatment. Patient was discharged on $30^{\text {th }}$ march 2015 with following medicines.

1) Above mentioned decoction,

2) Sharbat-e-Jigreen, $20 \mathrm{ml}$, twice daily,

3) Arq Makoh [Aqueous extract Solanum nigrum] 50ml+Arq Kasni [Aqueous extract Cichorium intybus] 50ml+Arq Biranjasif [Aqueous extract Achillea millefolium] 50ml, combined, twice daily,

4) Arq-e-Murakkab-e-Musaffiye-e-Khoon, $50 \mathrm{ml}$, twice daily

5) Habbe-e-Halteet 2 tab, SOS in case of acidity and flatulence.

Further follow up on $3^{\text {rd }}$ September 2015, analysis of LFT showed normalization of serum bilirubin total, SGOT, alkaline phosphatase and GGT values to $0.63 \mathrm{mg} / \mathrm{dl}, 25.1 \mathrm{IU} / \mathrm{L}, 120 \mathrm{IU} / \mathrm{L}$ and $57.7 \mathrm{U} / \mathrm{I}$ respectively. Viral count which was $1,88,115 \mathrm{IU} / \mathrm{ml}$ on $19^{\text {th }}$ February 2015 became undetectable on $3^{\text {rd }}$ September 2015. [Approximately 28 weeks post-treatment]. HBsAg was positive with titer value was $13.83 \mathrm{IU} / \mathrm{ml}$ [pretreatment] which became negative $[<0.08 \mathrm{lU} / \mathrm{ml}]$ approximately 28 weeks of treatment. Pre-treatment the values of EQ5D and TTO score were $60 \%$ and 21 which reduced to $0 \%$ and 4 after 28 week post-Unani treatment.

Case 2: SHN 45 years Indian female, known case of chronic hepatitis B, admitted in MUH on September 17, 2014 with chief complains of 1 ] yellow coloration of sclera and urine 2] mild continuous fever 3] General weakness and 4] pain in legs while walking for two months. Patient was investigated with haemogram, liver function test, kidney function test, ultrasonography abdomen, fibroscan and further HBV profile. After ultrasonography finding of splenomegaly, portal hypertension and provisional cirrhosis is, subsequently confirmed by fibroscan as a case of chronic hepatitis B induced cirrhosis of liver. HBV DNA quantitative value on 20 September 2014 was $2300 \mathrm{IU} / \mathrm{ml}$, HBsAg was positive with titer value 14.76 and $\mathrm{HBeAg}$ positive $2.59 \mathrm{~S} / \mathrm{CO}$ while $\mathrm{HBeAb}$ negative. Her fibroscan, showed ' $E$ ' median 16,1 kPa and 'CAP' median $180 \mathrm{~dB} / \mathrm{m}$ on $26^{\text {th }}$ September 2014 . The case was treated with following Unani treatment.

1. Primarily consisted of decoction of shahtara [Fumaria officinalis], sarphookah [Tephrosia purpurea], chiraita [Swertia chiraita], gule mundi [Sphaeranthus indicus], sandal surkh [Pterocarpus Santalinus], 5g each, in empty stomach, in the morning,

2. Arq Makoh [Aqueous extract Solanum nigrum] $50 \mathrm{ml}+$ Arq Kasni [Aqueous extract Cichorium intybus] 50ml+Arq Biranjasif [Aqueous extract Achillea millefolium ] 50ml, combined, twice daily,

\section{Majoon Dabeed-ul-ward, $10 \mathrm{~g}$ twice daily}

4. Habbe Kabid Naushadri, 3 tablet thrice daily after meal.

Pretreatment, LFT showed serum bilirubin total, SGPT, and alkaline phosphatase to be $8.5 \mathrm{mg} / \mathrm{dl}, 231 \mathrm{IU} / \mathrm{L}$ and $192 \mathrm{IU} / \mathrm{L}$ respectively on $17^{\text {th }}$ September 2014 which reduced to 5.0 $\mathrm{mg} / \mathrm{dl}, 73 \mathrm{IU} / \mathrm{L}$, and $101 \mathrm{IU} / \mathrm{L}$ respectively on $22^{\text {nd }}$ September 2015, after 1 week of Unani treatment. HBV DNA which was 2,300 pre-treatment, became undetectable on $11^{\text {th }}$ December 2014 post Unani treatment. Repeat fibroscan was performed on $9^{\text {th }}$ December 2014 revealed reduction in liver fibrosis to to ' $\mathrm{E}$ ' median 13,3 kPa and 'CAP' median $216 \mathrm{~dB} / \mathrm{m}$ from '16,1 $\mathrm{kPa}$ and 'CAP' median $180 \mathrm{~dB} / \mathrm{m}$ after approximately 12 weeks of treatment. Pre-treatment the values of EQ5D and TTO score were $40 \%$ and 17 which reduced to $5 \%$ and 3 after 12 week's post-Unani treatment.

Case 3: RJV 50 years Indian diabetic hypertensive male patient with a known case of alcoholic cirrhosis of liver, portal hypertension came to out-patient department of MUH on March 10, 2014 with chief complains of 1] loss of appetite 2] nausea 3] distension of abdomen 4] loss stool 3-4/ day 5] general weakness 6] insomnia 7] heaviness in epigastrium and 9] frequent giddiness. Serum bilirubin, SGPT, alkaline phosphatase and GGT were $2.10 \mathrm{mg} / \mathrm{dl}$, 54 IU/L, $220 \mathrm{IU} / \mathrm{L}$ and $205 \mathrm{IU} / \mathrm{L}$ respectively on $3^{\text {rd }}$ march 2014,. Ultrasonography showed cirrhotic liver with splenomegaly and portal hypertension on $10^{\text {th }}$ march 2014 . Patient blood sugar was at first put under control. Fibroscan performed, showed ' $\mathrm{E}$ ' median $49,6 \mathrm{kPa}$ and ' $\mathrm{CAP}$ ' median $343 \mathrm{~dB} / \mathrm{m}$ on $4^{\text {th }}$ march 2014. The case was treated with following Unani treatment started from 10 ${ }^{\text {th }}$ March 2014.

1. Cap Jigreen, 2 capsule, twice daily,

2. Arq Makoh [Aqueous extract Solanum nigrum] 50ml+Arq Kasni [Aqueous extract Cichorium intybus] 50ml+Arq ssue 08 | July-December 2015 
Biranjasif [Aqueous extract Achillea millefolium ] 50ml, combined, twice daily,

3. Qurs kuliya 2 tablet in morning,

4. Tab ajmaloon, 2 tablet twice daily,

A repeat LFT was revealed reduction in serum bilirubin, SGPT, alkaline phosphatase and GGT values from $2.10 \mathrm{mg} / \mathrm{dl}, 54 \mathrm{IU} / \mathrm{L}$, $220 \mathrm{IU} / \mathrm{L}$ and $2004 \mathrm{lU} / \mathrm{L}$ to $0.9 \mathrm{mg} / \mathrm{dl}, 16 \mathrm{IU} / \mathrm{L}, 133 \mathrm{lU} / \mathrm{L}$ and $631 \mathrm{IU} / \mathrm{L}$ respectively on $28^{\text {th }}$ march 2014 . A further repeated observation showed normal LFT pattern with serum bilirubin, SGPT, alkaline phosphatase and GGT values to $0.8 \mathrm{mg} / \mathrm{dl}$, $12 \mathrm{IU} / \mathrm{L}, 128 \mathrm{IU} / \mathrm{L}$ and $148 \mathrm{IU} / \mathrm{L}$ on $10^{\text {th }}$ may 2014. Fibroscan, showed reduction in liver fibrosis to ' $\mathrm{E}$ ' median $33,3 \mathrm{kPa}$ and 'CAP' median $292 \mathrm{~dB} / \mathrm{m}$ from ' $\mathrm{E}$ ' median 49,6 kPa and 'CAP' median $343 \mathrm{~dB} / \mathrm{m}$, repeated on $10^{\text {th }}$ may 2014 after 8 weeks of above mentioned Unani treatment. Haemogram and kidney function test were found normal pre and post-treatment. Pretreatment the values of EQ5D and TTO score were $25 \%$ and 17 which reduced to $1 \%$ and 2 after 6 week post-Unani treatment.

Table 1 provides a summary of the relevant biomarkers in these three cases.

Table 1. Summary of investigation in three cases with Unani treatment

\begin{tabular}{|c|c|c|c|c|c|c|c|}
\hline \multicolumn{2}{|c|}{ Investigation } & \multicolumn{2}{|l|}{ Case 1} & \multicolumn{2}{|l|}{ Case 2} & \multicolumn{2}{|l|}{ Case 3} \\
\hline & & $\begin{array}{l}\text { Pre-Treat- } \\
\text { ment }\end{array}$ & $\begin{array}{l}\text { Approx. } 28 \\
\text { wks. of treat- } \\
\text { ment }\end{array}$ & \begin{tabular}{|l} 
Pre- \\
Treat- \\
ment
\end{tabular} & $\begin{array}{l}\text { Approx. } \\
12 \text { wks. } \\
\text { of treat- } \\
\text { ment }\end{array}$ & $\begin{array}{l}\text { Pre- } \\
\text { Treat- } \\
\text { ment }\end{array}$ & $\begin{array}{l}\text { Approx. } 8 \\
\text { wkss. of treat- } \\
\text { ment }\end{array}$ \\
\hline \multirow[t]{4}{*}{ LFT } & \begin{tabular}{|l} 
Serum bilirubin \\
total (mg/dl)
\end{tabular} & 17.05 & 0.63 & 8.5 & 5.0 & 2.10 & 0.8 \\
\hline & SGPT (IU/L) & 1271 & 25.1 & 231 & 73 & 54 & $12 \mathrm{IU} / \mathrm{L}$ \\
\hline & \begin{tabular}{|l|} 
Alkaline \\
phosphatase \\
(IU/L)
\end{tabular} & 407 & 120.6 & 192 & 101 & 220 & 128 \\
\hline & GGT (IU/L) & 206.9 & 57.7 & UN & UN & 205 & 148 \\
\hline \multicolumn{2}{|c|}{$\begin{array}{l}\text { Fibroscan } \\
\text { ('E' median \& 'CAP' } \\
\text { median) }\end{array}$} & $\begin{array}{l}45,0 \mathrm{kPa} \& \\
148 \mathrm{~dB} / \mathrm{m}\end{array}$ & $\begin{array}{l}27,0 \mathrm{kPa} \& 185 \\
\mathrm{~dB} / \mathrm{m}(6 \text { weeks } \\
\text { of treatment) }\end{array}$ & $\begin{array}{l}16,1 \mathrm{kPa} \\
\& 180 \\
\mathrm{~dB} / \mathrm{m}\end{array}$ & $\begin{array}{l}13,3 \mathrm{kPa} \\
\& 216 \\
\mathrm{~dB} / \mathrm{m} /\end{array}$ & \begin{tabular}{|l|}
$49,6 \mathrm{kPa}$ \\
$\& 343$ \\
$\mathrm{~dB} / \mathrm{m}$
\end{tabular} & $\begin{array}{l}33,3 \mathrm{kPa} \& \\
292 \mathrm{~dB} / \mathrm{m}\end{array}$ \\
\hline \multicolumn{2}{|c|}{$\begin{array}{l}\text { Ultrasonography } \\
\text { Abdomen }\end{array}$} & \begin{tabular}{|l|} 
Cirrhosis of \\
liver with \\
portal hyper- \\
tension, gross \\
ascites and \\
contacted \\
edematous \\
gall bladder \\
with left renal \\
calculus
\end{tabular} & \begin{tabular}{|l|} 
Liver normal \\
size with coarse \\
echo texture
\end{tabular} & \begin{tabular}{|l|} 
Spleno- \\
megaly, \\
portal \\
hyper- \\
tension \\
and liver \\
cirrhosis \\
\end{tabular} & UN & \begin{tabular}{|l|} 
Cirrhotic \\
liver with \\
spleno- \\
megaly \\
and \\
portal \\
hyper- \\
tension
\end{tabular} & UN \\
\hline \multicolumn{2}{|c|}{ HBV DNA (IU/ml) } & $1,88,115$ & UN & 2300 & \begin{tabular}{|l}
20 Unde- \\
tectable
\end{tabular} & NA & NA \\
\hline
\end{tabular}

NA-not applicable; UN- unavailable

Table $\mathbf{2}$ is summary of quality of life assessment in these 3 cases.
Table 2: Effect on Quality of Life

\begin{tabular}{|l|l|l|l|l|}
\hline \multirow{2}{*}{} & \multicolumn{2}{|l|}{ EQ5D } & \multicolumn{2}{l|}{ TTO score } \\
\cline { 2 - 5 } & $\begin{array}{c}\text { Pre- } \\
\text { treatment }\end{array}$ & $\begin{array}{c}\text { Post- } \\
\text { treatment }\end{array}$ & $\begin{array}{c}\text { Pre- } \\
\text { treatment }\end{array}$ & $\begin{array}{c}\text { Post- } \\
\text { treatment }\end{array}$ \\
\hline Case 1 & $60 \%$ & $0 \%$ & 21 & 4 \\
\hline Case 2 & $40 \%$ & $5 \%$ & 17 & 3 \\
\hline Case 3 & $25 \%$ & $1 \%$ & 17 & 2 \\
\hline
\end{tabular}

\section{DISCUSSION}

The ultimate therapy for cirrhosis and end stage liver disease is liver transplantation. The major issues that remain in the care of the patient post liver transplantation are recurrent disease in the transplant, particularly HCV, and long term consequences of immunosuppressive agents such as hypertension, hyperlipidemia and renal disease. ${ }^{1}$ Even in the developed world, however, the number of donor organs available but the condition of the potential recipients limit the applicability of this transplantation, and thus validation of traditional therapies to halt or reverse fibrosis are urgently needed.

In our series, treatment was given with a decoction, consisted plants such as, shahtara [Fumaria officinalis], sarphookah [Tephrosia purpurea], chiraita [Swertia chiraita], gule mundi [Sphaeranthus indicus], Barg-e-hina [Lawsonia inermis], birhamdandi [Echinops echinatus], burada aabnoos [Diospyros ebenum], gule surkh [Rosa damsecenes], tukhm-e-kasni [Cichorium intybus], tukhm-e-branjasif [Achillea millefolium] and sandal surkh [Pterocarpus Santalinus] or Jigreen along with Arq makoh [Aqueous extract Solanum nigrum], Arq kasni [Aqueous extract Cichorium intybus] and Arq biranjasif [Aqueous extract Achillea millefolium], which have been used in single and poly-herbal form for chronic liver diseases since decades in Unani system of medicine.

The immune system [both the innate and the adaptive immune cells] plays an important role in fibrosis, since persistent inflammation almost always accompanies fibrosis. In our cases, reduction in fibrosis could be due to immunomodulatory effect of the constituents in above mentioned Unani treatment, proven in various animal models. ${ }^{11,21,22}$

Since chronic inflammation almost always precedes and accompanies fibrotic changes and the medicines that target the inflammatory cascade typically have antifibrotic activity. Moreover, because the vicious cycle of scar formation is initiated by oxidative stress, targeting ROS generation also reduces the inflammatory response, which will attenuate HSC activation and fibrogenesis. Antioxidants can attenuate ROS effects and hold promise as potential antifibrotic therapies, 
provided that sufficient antioxidant activity can be delivered to the sites of injury within the liver.

Antioxidants exert a preventive effect on hepatocyte injury but may also be directly antifibrogenic. ${ }^{6}$ On this principle, various constituents of given Unani treatment such as shahtara [Fumaria officinalis], sarphookah [Tephrosia purpurea], chiraita [Swertia chiraita], gule mundi [Sphaeranthus indicus], sandal surkh [Pterocarpus Santalinus], makoh [Solanum nigrum], kasni [Cichorium intybus] have been proved as potent antioxidant [inhibiting ROS generation], could be the plausible mechanism of reduction of fibrosis in fibroscan and liver regenerative effect. ${ }^{12,17-20,24}$ Moreover these drugs have also been proved for their hepatoprotective and anti-inflammatory activity ${ }^{13-16,24}$ and persistent inflammation almost always precedes and accompanies fibrosis. So medicines that target the inflammatory cascade and mitigate further liver injury [hepatoprotective] typically designated to possess antifibrotic activity, highlights the antifibrotic effect of Unani treatment.

${ }^{6}$ Return of liver function test toward normal and reduction in inflammation, could be due to hepato-protective and antiinflammatory effect of Unani treatment. HBV DNA became undetectable in case 2 , could be due to anti-hepatitis $B$ properties of constituents such as Swertia chiraita. ${ }^{23,24}$

Jigreen, has been proven for its effects on anorexia, pain in abdomen, nausea and vomiting, probably the cause for symptomatic relief in our cases. Jigreen has also reduced bilirubin levels and improved other liver biochemical markers. ${ }^{8,9}$ Chicory [kasni] has exhibited analgetic activity in mice in hot plate and tail-flick tests. ${ }^{7,9}$ Majoon Dabeed-ulward, is a compound formulation of Unani medicine, which contain Rosa damescene [Rose] as main drug, proven as hepatoprotective in various studies..$^{24,25}$

\section{CONCLUSION}

This case report provides a novel direction in which above mentioned Unani treatment can be used for regeneration of liver and halting progression of fibrosis in cirrhosis and for alleviation of constellation of symptoms. Unani treatment also improved quality of life in these three cases. Therefore further studies should be performed to warrant the antifibrotic and regenerative effect along with elucidation of mechanism of action of Unani treatment in cirrhosis of liver.

\section{CONFLICTS OF INTEREST}

None declared
We appreciate the co-operations of our patients in this study

\section{REFERENCES}

1. Schuppan D and Afdhal NH. Liver Cirrhosis. Lancet. 2008 March 8; 371(9615): 838-851. [PMid: 18328931]

2. Benvegnu L, Gios M, Boccato S, Alberti A. Natural history of compensated viral cirrhosis: a prospective study on the incidence and hierarchy of major complications. Gut 2004;53:744-749. [doi: 10.1136/gut.2003.020263] [PubMed][Cross Ref]

3. WHO. Age-standardized death rates of liver cirrhosis. [Online] Global Health Observatory [GHO] data. 2015 March. Available from: http://www.who.int/gho/alcohol/ harms_consequences/deaths_liver_cirrhosis/en./.

4. Mokdad AA, Lopez AD, Shahraz S, Lozano R, Mokdad AH, Stanaway J, Murray CJL and Naghavi M. Liver cirrhosis mortality in 187 countries between 1980 and 2010: a systematic analysis. BMC Medicine. 2014;12:145. [PMid:4168048]

5. Cohen-Naftaly M. Current status of novel antifibrotic therapies in patients with chronic liver disease. Therap Adv Gastroenterol. 2011;4(6):391-417. [PMid:3187682]

6. Kawada N, Seki S, Inoue M, Kuroki T. Effect of antioxidants, resveratrol, quercetin, and $\mathrm{N}$-acetylcysteine, on the functions of cultured rat hepatic stellate cells and Kupffer cells. Hepatology. 1998;27:1265-1274. [PubMed] [PMid:9581680]

7. Wesołowska A, Nikiforuk A, Michalska K, Kisiel W, Chojnacka-Wójcik E. Analgesic and sedative activities of lactucin and some lactucin-like guaianolides in mice. Journal of Ethnopharmacology.2006;107(2):254-258. [doi:10.1016/j.jep.2006.03.003. [PubMed][Cross Ref]

8. Tamanna SA. Effect of Jigreen on Patients Suffering from Hepatitis B, In Proceeding of the National Seminar on Reasearch Methodology in Unani Medicine. 1995 sep 5-10. New Delhi, India.

9. Ansari S, Fasihuzzaman, Md. Siddiqui A, Nikhat $S$ and Mushtaq S: Gilbert's Syndrome- A Case With Interpretation And Management In Unani Medicine. Int J Pharmacognosy 2015; 2(2) 98-101:.doi link: http://dx.doi. org/10.13040/IJPSR.0975-8232.IJP.2(2).98-101.

10. Ibn Sina (Avicenna). Al-Qanoon Fit-Tibb [H. Kantoori, trans]. Vol. 3, Part 1. New Delhi: Aijaz Publishing; 2010. P. 871-90.

11. Bafna AR, Mishra SH. Immunomodulatory activity of methanol extract of flower heads 
of Sphaeranthus indicus Linn. Ars Pharm. 2004;45:281-91. [PMid:7594985]

12. Shirwaikar A, Prabhu KS, Punitha IS. In vitro antioxidant studies of Sphaeranthus indicus (Linn.). Indian J Exp Biol. 2006;44:993-6 [PMid:17176673]

13. Ali A1, Shyum Naqvi SB, Gauhar S, Saeed R. Antiinflammatory and analgesic activities of ethanolic extract of Sphaeranthus indicus Linn. Pak J Pharm Sci. 2011;24:405-9. [PMid:21715276]

14. Ramchandaran S. Review on Sphaeranthus indicus Linn. (Koțțaikkarantai). Pharmacogn Rev. 2013;7:157-169. [PMid:3841994]

15. Mukherjee S, Sur A, Maiti BR. Hepato-protective effect of Swertia chirata on rats. Indian J. Exp. Biol. 1997;35:384388. [PMid:9315240]

16. Karan M1, Vasisht K, Handa SS. Antihepatotoxic activity of Swertia chirata on paracetamol and galactosamine induced hepatotoxicity in rats. Phytother Res. 1999;13: 95-101. [PMid:10190179]

17. Kshirsagar P1, Chavan J, Nimbalkar M, Yadav S, Dixit G, Gaikwad N. Phytochemical composition, antioxidant activity and HPLC profiles of Swertia species from Western Ghats. Nat Prod Res. 2015;29:780-4. doi: 10.1080/14786419.2014.986124. [PMID 25482162]

18. Gupta PC, Sharma N, Rao CV. A review on ethnobotany, phytochemistry and pharmacology offumaria indica (Fumitory). Asian Pac J Trop Biomed. 2012;2:665669. [PMid:3609363]

19. Arulmozhi V, Krishnaveni M, Karthishwaran K, Dhamodharan G, Mirunalini S. Antioxidant and antihyperlipidemic effect of Solanum nigrum fruit extract on the experimental model against chronic ethanol toxicity. Pharmacogn Mag. 2010;6(21): 42-50. [PMid:2881655]

20. Alam AN, Roy S, Anisuzzaman SM, Rafiquzzaman M. Antioxidant activity of the ethanolic extracts of leaves, stems and fruits of Solanum nigrum. Pharmacognosy Communications. 2012;2(3): 67-71. [PMid:24060280]

21. Amirghofrana A, Azadbakhtb M, Karimia MH. Evaluation of the immunomodulatory effects of five herbal plants. Journal of Ethnopharmacology. 2000;72(1-2,1):167-172. [PMid:10967468]

22. Kumar IVMLRS, Paul BN, Asthana R, Saxena A, Mehrotra $S$ and Rajan G. Swertia chirayita Mediated Modulation of Interleukin-1 $\beta$, Interleukin-6, Interleukin-10, Interferon- $\gamma$, and Tumor Necrosis Factor- $\alpha$ in Arthritic mice. Immunopharmacology and Immunotoxicology.
2003;25(4):573-583. [PMid:14686799]

23. Zhou NJ, Geng CA, Huang XY, Ma YB, Zhang XM, Wang $\mathrm{JL}$, Chen JJ. Anti-hepatitis $\mathrm{B}$ virus active constituents from Swertia chirayita. Fitoterapia. 2015;100:27-34. [PMid:25447162]

24. Siddiqui MA, Ansari S. Therapeutic effect of a Unani formulation on hepatitis $b$ surface antigen in chronic hepatitis b: a case series. Asian journal of pharmaceutical and clinical research 2015;8(4): 76-8.

25. Saxena M1, Shakya AK, Sharma N, Shrivastava S, Shukla S. Therapeutic efficacy of Rosa damascena Mill. on acetaminophen-induced oxidative stress in albino rats. J Environ Pathol Toxicol Oncol. 2012;31:193-201. [PMid:23339694] 